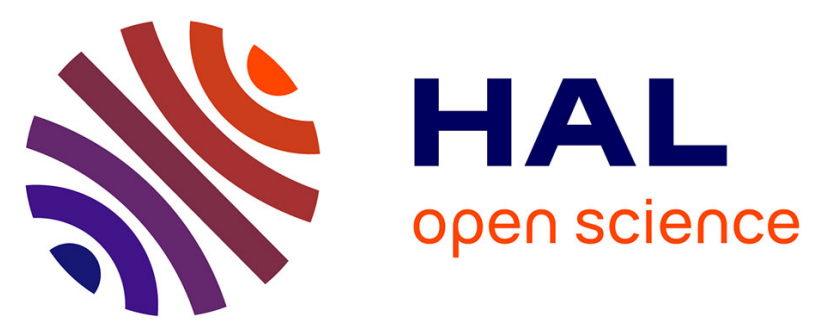

\title{
Increases of SET level and translocation are correlated with tau hyperphosphorylation at ser202/thr205 in CA1 of Ts65Dn mice
}

Emilie Dorard, Lucie Gorisse-Hussonnois, Chantal Guihenneuc-Jouyaux, Christelle Albac, Marie-Claude Potier, Bernadette Allinquant

\section{To cite this version:}

Emilie Dorard, Lucie Gorisse-Hussonnois, Chantal Guihenneuc-Jouyaux, Christelle Albac, MarieClaude Potier, et al.. Increases of SET level and translocation are correlated with tau hyperphosphorylation at ser202/thr205 in CA1 of Ts65Dn mice. Neurobiology of Aging, 2016, 46, pp.43-48. 10.1016/j.neurobiolaging.2016.06.010 . hal-01357903

\section{HAL Id: hal-01357903 \\ https: / hal.sorbonne-universite.fr/hal-01357903}

Submitted on 30 Aug 2016

HAL is a multi-disciplinary open access archive for the deposit and dissemination of scientific research documents, whether they are published or not. The documents may come from teaching and research institutions in France or abroad, or from public or private research centers.
L'archive ouverte pluridisciplinaire HAL, est destinée au dépôt et à la diffusion de documents scientifiques de niveau recherche, publiés ou non, émanant des établissements d'enseignement et de recherche français ou étrangers, des laboratoires publics ou privés.

\section{(ㅇ)(1) $\$$}

Distributed under a Creative Commons Attribution - NonCommercial - NoDerivatives| 4.0 
Brief communication

\title{
Increases of SET level and translocation are correlated with tau hyperphosphorylation at ser202/thr205 in CA1 of Ts65Dn mice
}

\author{
Emilie Dorard ${ }^{\mathrm{a}, 1}$, Lucie Gorisse-Hussonnois ${ }^{\mathrm{a}, 1}$, Chantal Guihenneuc-Jouyaux ${ }^{\mathrm{b}}$, \\ Christelle Albac ${ }^{c}$, Marie-Claude Potier ${ }^{\mathrm{c}}$, Bernadette Allinquant ${ }^{\mathrm{a}, *}$ \\ a INSERM UMR 894, Université Paris Descartes, Sorbonne Paris Cité, Faculté de Médecine, Paris, France \\ ${ }^{\mathrm{b}}$ EA 4064, Université Paris Descartes, Sorbonne Paris Cité, Faculté des Sciences Pharmaceutiques et Biologiques, Paris, France \\ ' INSERM U 1127, CNRS UMR 7225, Sorbonne Universités, UPMC Univ Paris 06 UMR S 1127, Institut du Cerveau et la Moelle épinière, ICM, Paris, France
}

\section{A R T I C L E I N F O}

\section{Article history:}

Received 30 November 2015

Received in revised form 18 May 2016

Accepted 14 June 2016

Available online 23 June 2016

\section{Keywords:}

Ts65Dn mice

SET translocation

Caspase cleaved APP

Hippocampus

Tau hyperphosphorylation

\begin{abstract}
A B S T R A C T
SET is a multifunctional protein, but when present in the cytoplasm, acts as a powerful inhibitor of phosphatase 2A. We previously observed that in CA1 of Down syndrome (DS) patients, the level of SET is increased, and SET is translocated to the cytoplasm and associated with the hyperphosphorylation of tau at ser202/thr205. The presence of SET in the cytoplasm in DS brains may play a role in the progression of the disease. Here, we show that in CA1 of 3-month-old Ts65Dn mice modeling DS, SET level is increased, and SET is translocated to the cytoplasm and associated with tau hyperphosphorylations at ser202/ thr205 and with amyloid precursor protein caspase cleaved as observed in Alzheimer disease brains. Tau hyperphosphorylation at ser356 and activation of other phosphatase $2 \mathrm{~A}$ targets such as the mammalian target of rapamycin and adenosine monophosphate protein kinases were also observed, suggesting deleterious mechanisms. We propose Ts65Dn mice as a model for therapeutic approaches focused on SET overexpression and its cytoplasmic translocation to slow down disease progression.
\end{abstract}

(c) 2016 Elsevier Inc. All rights reserved.

\section{Introduction}

Down Syndrome (DS) is the most common form of intellectual disability and results in a very large genetic risk for Alzheimer disease (AD). Although improved care of individuals with DS has significantly increased their life expectancy, it has led to a notable and concomitant increase in the number of adults with DS aged 35-55 years with AD type dementia (Coppus et al., 2012; Hartley et al., 2015; Strydom et al., 2013). Remarkably, almost $100 \%$ of adults with DS present deposition of microscopic amyloid plaques in their brains from early adult life. Treatments to slow down, stop, or prevent the risk of DS patients to shift to AD need to be developed.

In addition to amyloid deposits, tau hyperphosphorylation and neurofibrillary tangles (NFTs) are present in the brain of elderly DS individuals (Hartley et al., 2015). Tau hyperphosphorylation results from an increase of kinase and/or a decrease of phosphatase activity, which are both present in DS. Indeed, Dyrk1A kinase that phosphorylates tau at several sites is encoded by a gene mapping to human chromosome 21, and thus is overexpressed and accumulates in NFTs in DS patients (Kimura et al., 2007; Liu et al., 2008; Ryoo

\footnotetext{
* Corresponding author at: Université Paris Descartes, Sorbonne Paris Cité, INSERM UMR 894, 75014 Paris, France. Tel.: 331407892 41; fax: 33145807293.

E-mail address: bernadette.allinquant@inserm.fr (B. Allinquant).

${ }^{1}$ These authors contributed equally to this work.
}

et al., 2007). In addition, a specific decrease of phosphatase $2 \mathrm{~A}$ (PP2A), the major phosphatase involved in tau dephosphorylation, is present in DS brains, whereas phosphatases $1,2 \mathrm{~B}$, and 5 are unmodified (Liang et al., 2008). Decrease of PP2A activity may be associated with the presence of the PP2A inhibitor 2, also called SET, in the neuronal cytoplasm. SET is a multifunctional protein that inhibits the acetylation of histones, acts as a transcription factor, stimulates cdk5 activity, and inhibits PP2A (Compagnone et al., 2000; Li et al., 1996; Qu et al., 2002; Seo et al., 2001). In CA1 of AD and DS patients (45-58 year old), we found that SET is increased and translocated to the cytoplasm (Facchinetti et al., 2014). When located in the neuronal cytoplasm, SET binds to PP2A, inhibiting its activity and leading to an increase in tau phosphorylation. (Arnaud et al., 2011; Bolognin et al., 2012; Chasseigneaux et al., 2014; Chohan et al., 2006; Wang et al., 2010). In AD brains, SET translocation was correlated to the increase of amyloid precursor protein caspase cleaved in its C-terminal part (APPCC). In addition, the overexpression of APPcc in the CA1 of wild-type mice leads to the translocation of endogenous SET and increase of tau phosphorylation at ser202/thr205 (Facchinetti et al., 2014). Thus SET appears as an actor of the progression of the disease.

Here, we analyzed SET level and translocation in CA1 of Ts65Dn mice, the best-characterized and most widely used mouse model of DS, trisomic for a segment of chromosome 16 extending between 

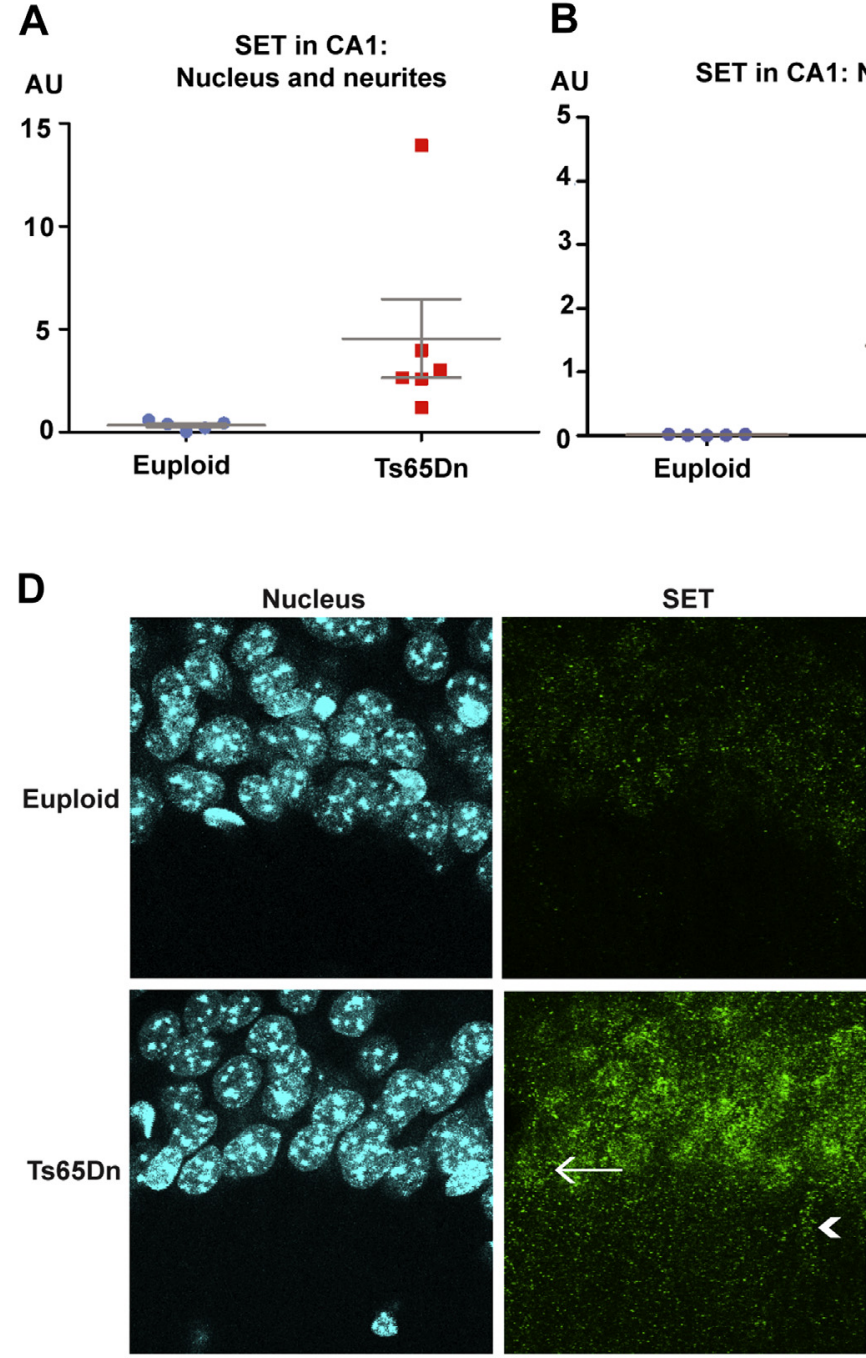

E

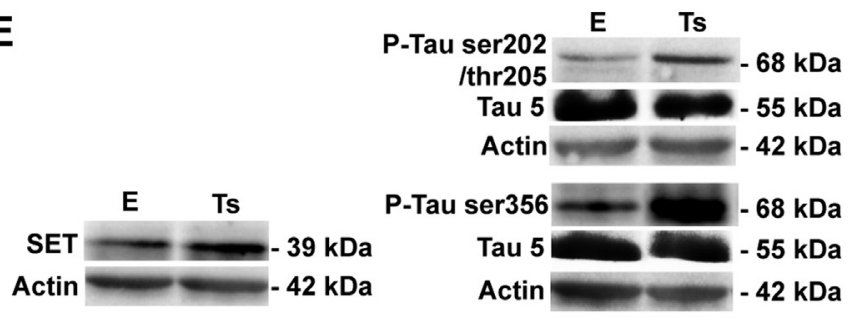

B C
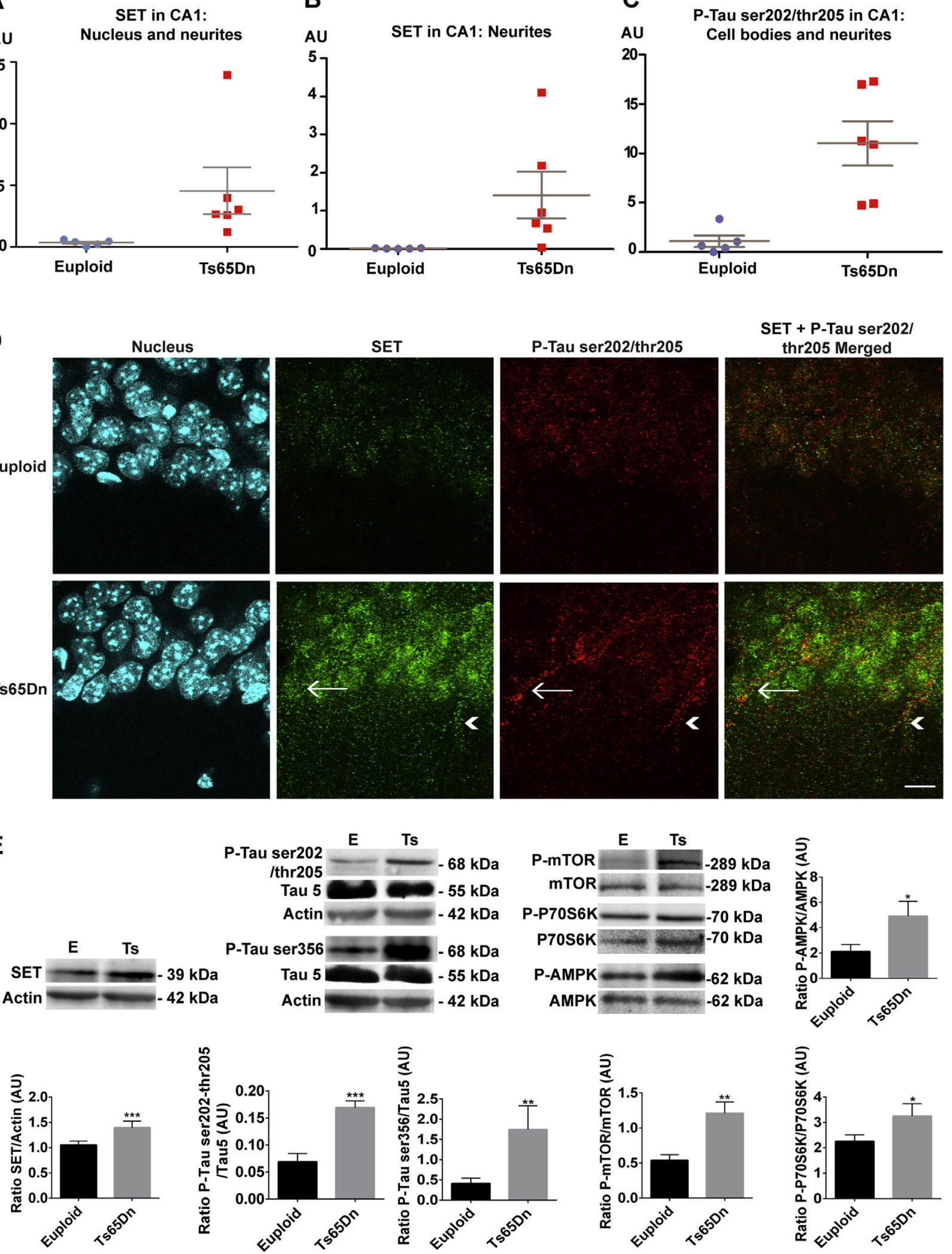

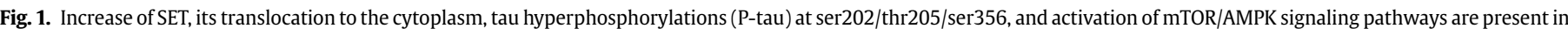

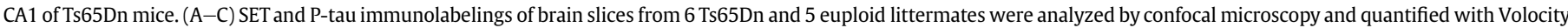

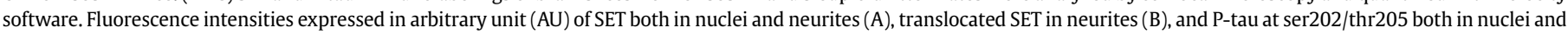

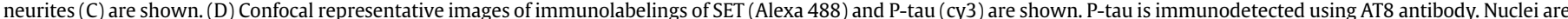

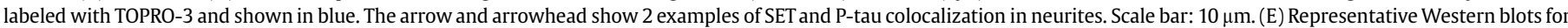

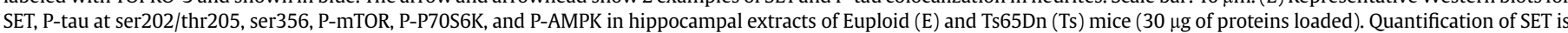


genes Mrp139 and Znf295 and containing approximately 92 orthologues of human chromosome 21 genes (Sturgeon and Gardiner, 2011). This murine model recapitulates several fundamental features of DS, including cognitive deficits and alterations in brain morphology and function (Reeves et al., 1995). We show here that SET is overexpressed and translocated to the cytoplasm and that tau is hyperphosphorylated at ser202/thr205 in CA1 of Ts65Dn mice modeling DS, as in the brain of DS individuals. These events are correlated with an increase of APPcc. Additional Tau hyperphosphorylation at ser356 and activation of mammalian target of rapamycin (mTOR) and adenosine monophosphate protein kinase (AMPK) signaling pathways are observed in hippocampi of Ts65Dn, suggesting deleterious mechanisms.

\section{Material and methods}

\subsection{Animals and ethics}

Male mice were produced from breeders of the Jackson Laboratories (B6EiC3Sn.BLi males with B6EiC3Sn.BLiA-Ts(1716)65Dn/ DnJ females). All experiments were conducted in accordance with the ethical standards of French and European regulations (European Communities Council Directive of 24 November 1986). The supervisor of in vivo studies (Marie-Claude Potier) received official authorization from the French Ministry of Agriculture to carry out research and experiments on animals (authorization no. A-75-2138). Mice were genotyped as previously described (Duchon et al., 2011).

\subsection{Antibodies}

Primary antibody for Amyloid Precursor Protein caspase cleaved (Millipore, AB 5942, Saint-Quentin en Yvelines, France) was diluted to $1 / 200$. SET primary antibody (Santa-Cruz H-120, Heidelberg, Germany) was diluted to $1 / 100$ for immunohistochemistry. Its specificity was checked previously (Facchinetti et al., 2014). Tau phosphorylated at ser202/thr205 (AT8 antibody Innogenetics, BR-03, Courtaboeuf, France) was used to $1 / 200$ for immunohistochemistry as previously used (Facchinetti et al., 2014).

For Western blotting, SET and AT8 antibodies were diluted to 1/500, tau phosphorylated at ser356 (ab 75603, Abcam, Cambridge, UK) was diluted to 1/1000; anti-Tau-5 for total Tau (mAb 577801, Calbiochem, Merck Chemicals Limited, Nottingam, UK) to 1/1000; anti-phospho mTOR (ser2448) to $1 / 500$, anti-mTOR (L27D4) to 1/5000 both from Cell Signaling Technology (Ozyme, SaintQuentin-en-Yvelines, France); anti-phospho P70S6 kinase at thr389 to $1 / 1000$ and anti-P70S6 kinase to $1 / 1000$, both from Cell Signaling Technology; anti-phospho AMPK at thr172 to $1 / 1000$ and anti-AMPK to $1 / 1000$, both from Cell Signaling Technology, antiactin (MAB 1501R, Millipore) to $1 / 5000$.

Secondary antibodies for immunohistochemistry were from Jackson Immunoresearch West Grove. Anti-rabbit secondary antibody Alexa Fluor 488 or cy3 was diluted respectively to $1 / 200$ and to $1 / 500$. Anti-mouse biotinylated antibody was diluted to $1 / 50$ and streptavidin cy3 to $1 / 200$. Secondary goat anti-mouse horseradish peroxidase (Biorad, Marnes-la-Coquette, France) diluted to 1/5000 and donkey anti-rabbit horseradish peroxidase (GE Healthcare, Vélizy-Villacoublay, France) diluted to 1/1000 were used for immunoblots.

\subsection{Immunohistochemistry}

Six Ts65Dn male mice and 5 euploid littermates of 3 month old were analyzed for immunohistochemistry. To this end, mice were deeply anesthezied with pentobarbital and perfused through the ascending aorta with $4 \%$ paraformaldehyde in phosphate-buffered saline (PBS) $0.1 \mathrm{M}$.

Brains were removed and postfixed overnight in the same solution and cryoprotected by incubation in a $30 \%$ sucrose solution for 48 hours. Brains were then frozen by immersion in isopentane and stored at $-80^{\circ} \mathrm{C}$ until sections were cut. Floating sagittal brain sections $(40 \mu \mathrm{m})$ were cut on a freezing microtome, collected and stored at $4{ }^{\circ} \mathrm{C}$ in sodium azide $2.5 \%$ in $0.1 \mathrm{M}$ (PBS) until analysis.

Immunohistochemistry for APPcc, SET, and phosphorylated tau (P-tau) was performed as previously described. Briefly, after blocking for 1 hour at room temperature in PBS with 5\% bovine serum albumin and $0.1 \%$ Triton X100, the sections were incubated for overnight at $4{ }^{\circ} \mathrm{C}$ in primary antibodies diluted in the blocking buffer. After 3 rinses of 10 minutes in PBS, sections were incubated for 90 minutes at room temperature in the secondary antibodies diluted in PBS. The sections were then rinsed 3 times in PBS and labeled by $0.1 \mu \mathrm{M}$ TO-PRO-3 (Life Technologies, Illkirch, France) for 15 minutes. The sections were mounted in Fluoromount (Clinisciences, Nanterre, France).

Immunofluorescence was performed at the PICPEN platform (INSERM, UMR 894) using a TCS SP5 confocal imaging system equipped with DPSS $561 \mathrm{~nm}$ and HeNe $633 \mathrm{~nm}$ lasers (Leica Microsystems, Mannheim, Germany). Digital images of 8 bit were collected in a sequential mode using an x63 plan Apochromat oil immersion objective, a numerical aperture of 1.4 and the pinhole size "airy 1 ". Sections of $0.5 \mu \mathrm{m}$ were performed. For each experiment of the Ts65Dn and their euploid littermate mice, laser intensity and image settings were adjusted and kept constant.

Image fluorescence quantification of the different sections was performed in Volocity software.

\subsection{Tissue extraction}

Four Ts65Dn male mice and 4 euploid littermates of 3 month old were analyzed for Western blotting. To this end, mice were sacrificed, their brain extracted and hippocampi were dissected and sonicated at $4{ }^{\circ} \mathrm{C}$ in 4 volumes of $50 \mathrm{mM}$ Tris buffer ( $\mathrm{pH} 7.4$ ), $0.15 \mathrm{M}$ $\mathrm{NaCl}$ (TBS), 1\% Triton X100, protease inhibitor cocktail 1X (Complete, Roche Diagnostics, Mannheim, Germany) phosphatase inhibitors ( $2 \mathrm{mM} \mathrm{Na}_{3} \mathrm{VO}_{4}$ and $100 \mathrm{mM} \mathrm{NaF}$ ). Proteins were quantified using micro BCA Protein assay kit (Thermo Scientific, Illkirsch, France).

\subsection{Western blotting}

Standard SDS-PAGE on $10 \%$ Tris- $\mathrm{HCl}$ acrylamide gels and Western blotting were performed. After electrophoresis, the proteins were transferred onto polyvinylidene fluoride membranes. After saturation in TBS-Tween $0.2 \%$ with $5 \%$ low fat milk, the membranes were incubated overnight at $4{ }^{\circ} \mathrm{C}$ with primary antibodies. After 3 rinses with TBS-Tween $0.2 \%$, membranes were incubated with species-specific peroxidase-conjugated secondary antibodies for 1 hour at room temperature. The peroxidase signal was visualized by enhanced chemiluminescence (ECL GE-Healthcare). Immunoblots

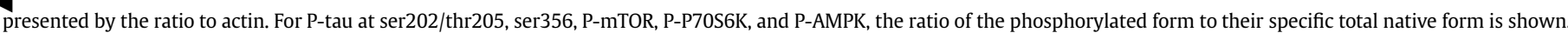

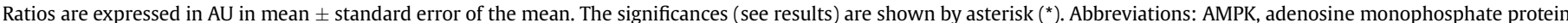

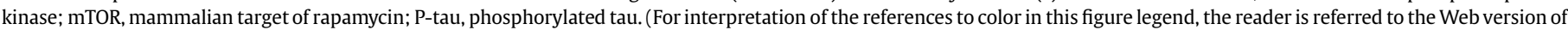
this article.) 
were quantified with the Chemi-Doc Analyzer (Biorad). For mTOR, P70S6K, AMPK, Tau, immunoblots were first performed for the phosphorylated epitopes, and after stripping, the membranes were incubated with the antibody to the respective total protein.

\subsection{Statistical analysis}

Analyses of the fluorescence levels were performed using Mann-Whitney test. Correlation between 2 of the different immunolabelings was evaluated by Spearman's rho tests (Fredricks and Nelsen, 2007).

\section{Results}

In CA1 of Ts65Dn mice, SET was localized both in the nucleus and in the neurites, whereas in euploid littermates, SET was exclusively present in the nucleus (Fig. 1A,B,D). We observed a significant increase of SET immunolabeling both in the cell body including the nucleus and in neurites in CA1 of the Ts65Dn as compared with euploid mice (Ts65Dn vs. euploid mice: $p=0.004$; Fig. 1A). The increase of SET immunolabeling was also significant in the neurites (Ts65Dn vs. euploid mice: $p=0.004$; Fig. 1B). In addition, P-tau at ser202/thr205 was immunodetected by the AT8 antibody at low levels in the euploid mice and at significantly higher levels in Ts65Dn mice (Ts65Dn vs. euploid mice: $p=0.004$; Fig. 1C). The level of SET translocated to the cytoplasm was significantly correlated with the total level of SET (Speerman rho $=0.84 ; p=0.001$ ).

SET and P-tau at ser202/thr205 levels in Ts65Dn and euploid mice were significantly correlated (Speerman rho $=0.84$; $p=0.001)$. Similar results were obtained when considering the levels of SET and P-tau in neurites only (Speerman rho $=0.87$; $p=0.0001$ ). Double immunohistochemistry showed that SET and P-tau colocalized both in the cytoplasm and in the neurites (Fig. 1D).

The increase in SET level, the translocation of SET in the cytoplasm and neurites, and the increase of P-tau in CA1 of Ts65Dn are similar to what we observed in CA1 of DS patients (Facchinetti et al., 2014).

The differences observed in SET and P-tau at ser202/thr205 levels between Ts65Dn and euploid mice were confirmed by immunoblotting (Fig. 1E; SET $p=0.009$; P-tau at ser202/thr205 $p=0.001$ ). Significant increase in P-tau levels were also observed at ser356 in Ts65Dn mice (Fig. 1E; $p=0.02$ ).

We then examined the activation of mTOR complex 1 and of the AMPK signaling pathways, already observed when PP2A is inhibited (Magnaudeix et al., 2013). In Ts65Dn, a significant increase in the phosphorylation of mTOR at ser2448 $(p=0.03)$ and of its substrate P70S6K at thr389 ( $p=0.049$ ) was observed (Fig. 1E), as in DS patients (Iyer et al., 2014). We also observed in Ts65Dn an increase in the phosphorylation of AMPK at thr172 as observed after PP2A inhibition ( $p=0.049$ ) (Magnaudeix et al., 2013). These activations of mTORC1 and AMPK signaling pathways suggest that in addition to tau hyperphosphorylation other cell events may be triggered such as autophagy (Magnaudeix et al., 2013; Tramutola et al., 2016).

As we previously showed that overexpression of APPcc in CA1 of wild-type mice is able to induce SET translocation not only in cytoplasm but also in neurites, we examined the localization and the level of APPcc in Ts65Dn and euploid mice. In euploid mice, APPcc was present at neuron terminals whereas in Ts65Dn, APPcc was highly present in the neuronal cytoplasm and in neurites leading to a significant increase of APPcc levels (Ts65Dn vs. euploid mice: $p=0.004$; Fig. 2). The APPcc levels correlated with the amount of SET (Speerman rho $=0.77 ; p=0.005$ ) and P-tau at ser202/thr205 (Speerman rho $=0.72 ; p=0.013$ ).

Finally, we evaluated the putative apoptotic markers by quantification of the number and morphology of nuclei labeled by
A

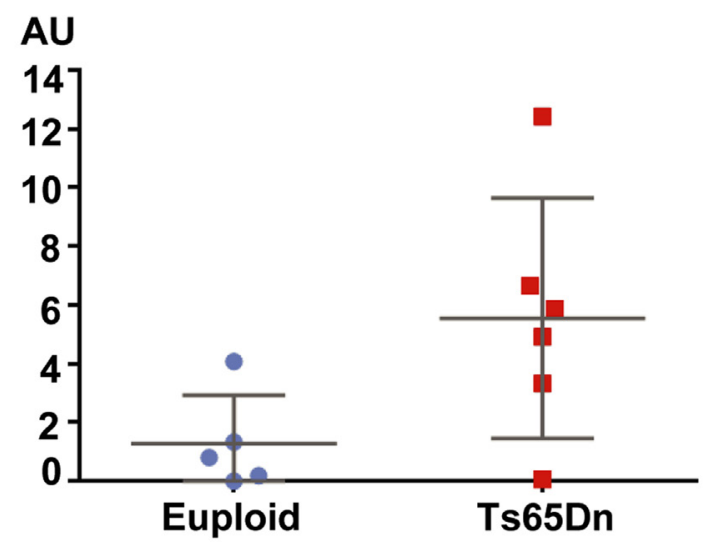

B

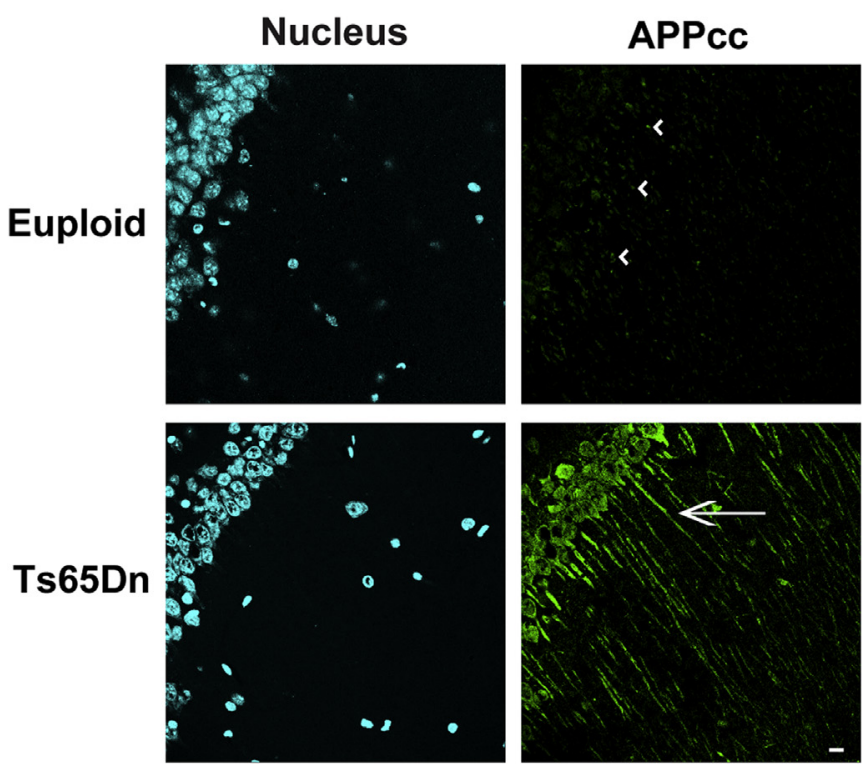

C

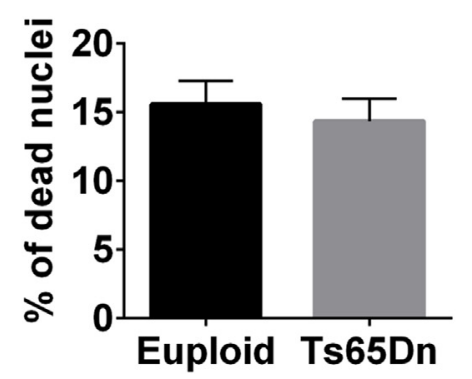

Fig. 2. Increase of APPcc in CA1 of Ts65Dn mice without changes in apoptotic nuclei. (A) Fluorescence intensity of APPcc detected in CA1 by immunolabeling of brain slices from the 6 Ts65Dn and 5 euploid littermates was analyzed by confocal microscopy and quantified using Volocity software. Data are expressed in arbitray units (AU). (B) Representative immunolabeling of APPcc in Ts65Dn and euploid littermate mice. Nuclei are labeled with TOPRO-3 and presented in blue. Note the presence of APPcc in terminals (arrowheads) in euploid littermates while it is highly detected in the neuronal cytoplasm and neurites of Ts65Dn mice (arrow). Scale bar: $10 \mu \mathrm{m}$. (C) Percentage of apoptotic nuclei in CA1 from 5 Euploid and 6 Ts65Dn mice was evaluated in sections labeled for SET, phosphorylated tau (P-tau) at ser202/thr205, and APPcc. The nuclei were labeled by TOPRO-3. The apoptotic nuclei were counted in each field of 70-90 cells. A total of about 1100 cells were counted for each genotype. Results are presented as mean \pm standard error of the mean. No significant difference was observed between euploid and Ts65Dn mice $(p=0.6017)$. Abbreviation: APPcc, amyloid precursor protein caspase cleaved. (For interpretation of the references to color in this figure legend, the reader is referred to the Web version of this article.) 
TOPRO-3. The percentage of dead cells was not significantly different between euploid and Ts65Dn mice (Fig. 2C).

\section{Discussion}

In this report, we show that SET is increased, translocated to the cytoplasm of neurons from the CA1 of Ts65Dn mice leading to an increase of tau phosphorylation at ser202/thr205 as observed in DS and AD patients (Facchinetti et al., 2014). In addition, we also found an increase in tau phosphorylation at ser356 and activation of mTOR and AMPK signaling pathways, 2 other hallmarks of PP2A inhibition.

Overexpressed Dyrk1A contributes to the neurofibrillar degeneration in DS. In $60 \%$ of sporadic AD, Dyrk1A positive NFTs were detected. However, a much higher percentage of Dyrk1A positive NFTs was present in DS patients as compared with sporadic AD cases (Ferrer et al., 2005; Wegiel et al., 2008). Dyrk1A predominantly phosphorylates tau at thr212 priming the GSK3-dependent phosphorylation of tau at ser208 but also at several other sites including ser202 and thr205 (Liu et al., 2008; Woods et al., 2001). Increased tau phosphorylation at ser202/thr205 has been detected before the formation of NFTs in AD brains (Braak et al., 1994) and is present in dystrophic neurites and around amyloid cores in transgenic AD mouse models (Laporte et al., 2008; Nodo-Saita et al., 2004; Otth et al., 2002). Tau phosphorylation at ser202 enhances its polymerization, whereas phosphorylation at ser202 and thr205 not only induces polymerization but also facilitates filament formation (Rankin et al., 2005). Phosphorylation of tau at ser202/thr205 in the brain of DS individuals may reflect AD pathology in DS. We previously showed in an ex vivo model that increase of SET in the neuronal cytoplasm induced tau phosphorylation at ser202/thr205 and additional phosphorylations at other sites (Chasseigneaux et al., 2014). We show here that tau at ser356 was also hyperphosphorylated, as already observed when PP2A is inhibited (Bennecib et al., 2001; Magnaudeix et al., 2013), suggesting several sites for tau hyperphosphorylation. In addition, we observed that the overexpression of APPcc in the CA1 of wild-type mice is sufficient to induce the translocation of endogenous SET and thus the increased phosphorylation of tau at ser202/thr205 (Facchinetti et al., 2014). Consequently, SET translocated in the cytoplasm increases tau phosphorylation at ser202/thr205 thus being involved in the progression of the disease in AD but also in DS.

We observed here that SET and P-tau levels at ser202/thr205 are significantly correlated with APPcc levels. Increase of APPcc could result from the overexpression of APP in Ts65Dn mice and enhanced processing. Overexpression of wild-type APP induces activation of caspase- 3 in neurons both in vivo and in vitro leading to the accumulation of APPcc (Nishimura et al., 1998, 2002). Apoptosis has been observed in DS brain patients (Anderson et al., 2000), but increase in Terminal deoxynucleotidyl transferase dUTP nick end labeling (TUNEL) positive cells or in caspase had not been observed in 12-month-old Ts65Dn mice, contrary to a decrease in Bcl-XL (Rueda et al., 2011). We did not observe any increase in apoptotic nuclei in the CA1 of Ts65Dn mice unlike the increase in APPcc. APP caspase cleavage is an event observed at early stages of AD (Ayala-Grosso et al., 2002; Banwait et al., 2008; Zhao et al., 2003). We used 3-month-old mice, whereas most of the studies were performed on 12-month-old animals. In this sense, the loss of cholinergic neurons in basal forebrain in Ts65Dn mice and its association with cognitive decline start after 4 months (Granholm et al., 2000). We previously observed in the brains of 3 DS patients that only 1 (48 years old) had an increase of APPcc suggesting that in DS, other factors resulting from increased expression of genes from chromosome 21 may be responsible for the increase of SET, its translocation to the cytoplasm, and the increase of tau phosphorylation at ser202/thr205. Indeed, both tau-phosphorylated sites recognized by the AT8 antibody were also detected in the DS mouse model Ts1Cje in the absence of NFT formation and of APP-triplicated gene (Shukkur et al., 2006).

Translocation of SET to the cytoplasm was found in 5 of the 6 Ts65Dn and correlated with SET levels: the higher the level of SET the higher the translocation. The mouse without translocation of SET had the lowest P-tau level at ser202/thr205 confirming the relationship between SET translocation and tau phosphorylation at ser202/thr205. In hippocampus of DS patients, SET was largely increased and associated to tau phosphorylation at ser202/thr205 (Facchinetti et al., 2014). The increased SET levels in Ts65Dn is not due to a higher gene copy number like APP and Dyrk1A (Duchon et al., 2011) because SET maps to Mouse chromosome 2 (Asaka et al., 2008) and to Human chromosome 9 (von Lindern et al., 1992). However, SET expression could be regulated by a gene or a set of genes that are in 3 copies in DS. As the translocation of SET in the neuronal cytoplasm of CA1 is associated with high levels of SET, molecules able either to decrease the level of SET or decrease the interaction of SET with PP2A would allow to slow down the progression of the disease particularly the shift to AD pathology as assessed by tau hyperphosphorylation. The activations of the mTOR and AMPK signaling pathways in Ts65Dn as observed in conditions of PP2A inhibition suggest that other deleterious mechanisms such as inhibition of autophagy, which can induce the accumulation of protein oxidative damage, may be the consequence of SET in the cytoplasm inhibiting PP2A. Indeed, PP2A inhibition either by okadaic acid or by knock down of PP2A catalytic subunit activates these signaling pathways, which were associated to the autophagy inhibition (Magnaudeix et al., 2013). Activation of mTOR was already observed in DS patients (Iyer et al., 2014). More recently, it has been reported an hyperphosphorylation of mTOR coupled with the reduction of autophagosome formation in hippocampi of Ts65Dn (Tramutola et al., 2016).

Taken together, we suggest that Ts65Dn mice could be a model to test therapeutic approaches aiming at decreasing SET level and its translocation to the cytoplasm leading to tau hyperphosphorylation and associated deleterious mechanisms, responsible of the disease progression in DS.

\section{Disclosure statement}

There are no actual or potential conflicts of interest between the authors and this work.

\section{Acknowledgements}

This work was supported by Fondation Jérôme Lejeune, France and Institut National de la Santé et de la Recherche Médicale, France.

\section{References}

Anderson, A.J., Stoltzner, S, Lai, F Su, J, Nixon, R. A, 2000. Morphological and biochemical assessment of DNA damage and apoptosis in Down syndrome and Alzheimer disease, and effect of postmortem tissue archival on TUNEL. Neurobiol. Aging 21, 511-524.

Arnaud, L., Chen, S., Liu, F., Li, B., Khatoon, S., Grundke-Iqbal, I., Iqbal, K., 2011. Mechanism of inhibition of PP2A activity and abnormal hyperphosphorylation of tau by I2(PP2A)/SET. FEBS Lett. 585, 2653-2659.

Asaka, M.N., Murano, K., Nagata, K., 2008. Sp1-mediated transcription regulation of TAF-Ialpha gene encoding a histone chaperone. Biochem. Biophys. Res. Commun. 376, 665-670.

Ayala-Grosso, C., Ng, G., Roy, S., Robertson, G.S., 2002. Caspase-cleaved amyloid precursor protein in Alzheimer's disease. Brain Pathol. 12, 430-441.

Banwait, S., Galvan, V., Zhang, J., Gorostiza, O.F., Ataie, M., Huang, W., Crippen, D. Koo, E.H., Bredesen, D.E., 2008. C-terminal cleavage of the amyloid-beta protein 
precursor at Asp664: a switch associated with Alzheimer's disease. J. Alzheimers Dis. 13, 1-16.

Bennecib, M., Gong, C.X., Grundke-Iqbal, I., Iqbal, K., 2001. Inhibition of PP-2A upregulates CaMKII in rat forebrain and induces hyperphosphorylation of tau at Ser 262/356. FEBS Lett. 490, 15-22.

Braak, E., Braak, H., Mandelkow, E.M., 1994. A sequence of cytoskeleton changes related to the formation of neurofibrillary tangles and neuropil threads. Acta Neuropathol. 87, 554-567.

Bolognin, S., Blanchard, J., Wang, X., Basurto-Islas, G., Tung, Y.C., Kohlbrenner, E., Grundke-Iqbal, I., Iqbal, K., 2012. An experimental rat model of sporadic Alzheimer's disease and rescue of cognitive impairment with a neurotrophic peptide. Acta Neuropathol. 123, 133-151.

Chasseigneaux, S., Clamagirand, C., Huguet, L., Gorisse-Hussonnois, L., Rose, C., Allinquant, B., 2014. Cytoplasmic SET induces tau hyperphosphorylation through a decrease of methylated phosphatase 2A. BMC Neurosci. 15, 82-96.

Chohan, M.O., Khatoon, S., Iqbal, I.G., Iqbal, K., 2006. Involvement of I2PP2A in the abnormal hyperphosphorylation of tau and its reversal by Memantine. FEBS Lett. 580, 3973-3979.

Compagnone, N.A., Zhang, P., Vigne, J.L., Mellon, S.H., 2000. Novel role for the nuclear phosphoprotein SET in transcriptional activation of P450c17 and initiation of neurosteroidogenesis. Mol. Endocrinol. 14, 875-888.

Coppus, A.M., Schuur, M., Vergeer, J., Janssens, A.C., Oostra, B.A., Verbeek, M.M., van Duijn, C.M., 2012. Plasma beta amyloid and the risk of Alzheimer's disease in Down syndrome. Neurobiol. Aging 33, 1988-1994.

Duchon, A., Raveau, M., Chevalier, C., Nalesso, V., Sharp, A.J., Herault, Y., 2011. Identification of the translocation breakpoints in the Ts65Dn and Ts1Cje mouse lines: relevance for modeling Down syndrome. Mamm. Genome. 22, 674-684.

Facchinetti, P., Dorard, E., Contremoulins, V., Gaillard, M.C., Deglon, N., Sazdovitch, V., Guihenneuc-Jouyaux, C., Brouillet, E., Duyckaerts, C., Allinquant, B., 2014. SET translocation is associated with increase in caspase cleaved amyloid precursor protein in CA1 of Alzheimer and Down syndrome patients. Neurobiol. Aging 35, 958-968.

Ferrer, I., Barrachina, M., Puig, B., Martinez de Lagran, M., Marti, E., Avila, J., Dierssen, M., 2005. Constitutive Dyrk1A is abnormally expressed in Alzheimer disease, Down syndrome, Pick disease, and related transgenic models. Neurobiol. Dis. 20, 392-400.

Fredricks, G.A., Nelsen, R.B., 2007. On the relationship between Spearman's rho and Kendall's tau for pairs of continuous random variables. J. Stat. Plann. Inference 137, 2143-2150.

Granholm, A.C., Sanders, L.A., Crnic, L.S., 2000. Loss of cholinergic phenotype in basal forebrain coincides with cognitive decline in a mouse model of Down's syndrome. Exp. Neurol. 161, 647-663.

Hartley, D., Blumenthal, T., Carrillo, M., DiPaolo, G., Esralew, L., Gardiner, K., Granholm, A.C., Iqbal, K., Krams, M., Lemere, C., Lott, I., Mobley, W., Ness, S., Nixon, R., Potter, H., Reeves, R., Sabbagh, M., Silverman, W., Tycko, B., Whitten, M., Wisniewski, T., 2015. Down syndrome and Alzheimer's disease: common pathways, common goals. Alzheimers Dement. 11, 700-709.

Iyer, A.M., van Scheppingen, J., Milenkovic, I., Anink, J.J., Adle-Biassette, H., Kovacs, G.G., Aronica, E., 2014. mTOR hyperactivation in down syndrome hippocampus appears early during development. J. Neuropathol. Exp. Neurol. 73, 671-683.

Kimura, R., Kamino, K., Yamamoto, M., Nuripa, A., Kida, T., Kazui, H., Hashimoto, R., Tanaka, T., Kudo, T., Yamagata, H., Tabara, Y., Miki, T., Akatsu, H., Kosaka, K., Funakoshi, E., Nishitomi, K., Sakaguchi, G., Kato, A., Hattori, H., Uema, T., Takeda, M., 2007. The DYRK1A gene, encoded in chromosome 21 Down syndrome critical region, bridges between beta-amyloid production and tau phosphorylation in Alzheimer disease. Hum. Mol. Genet. 16, 15-23.

Laporte, V., Ait-Ghezala, G., Volmar, C.H., Ganey, C., Ganey, N., Wood, M., Mullan, M., 2008. CD40 ligation mediates plaque-associated tau phosphorylation in betaamyloid overproducing mice. Brain Res. 1231, 132-142.

Li, M., Makkinje, A., Damuni, Z., 1996. The myeloid leukemia-associated protein SET is a potent inhibitor of protein phosphatase 2A. J. Biol. Chem. 271, 11059-11106.

Liang, Z., Liu, F., Iqbal, K., Grundke-Iabal, I., Wegiel, J., Gong, C.X., 2008. Decrease of protein phosphatase $2 \mathrm{~A}$ and its association with accumulation and hyperphosphorylation of tau in Down syndrome. J. Alzheimers Dis. 13, 295-302.

Liu, F., Liang, Z., Wegiel, J., Hwang, Y.W., Iqbal, K., Grundke-Iqbal, I., Ramakrishna, N., Gong, C.X., 2008. Overexpression of Dyrk1A contributes to neurofibrillary degeneration in Down syndrome. Faseb J. 22, 3224-3233.

Magnaudeix, A., Wilson, C.M., Page, G., Bauvy, C., Codogno, P., Leveque, P., Labrousse, F. Corre-Delage, M., Yardin, C., Terro, F., 2013. PP2A blockade inhibits autophagy and causes intraneuronal accumulation of ubiquitinated proteins. Neurobiol. Aging 34, 770-790.
Nishimura, I., Uetsuk, T., Dani, S.U., Ohsawa, Y., Saito, I., Okamura, H., Uchiyama, Y., Yoshikawa, K., 1998. Degeneration in vivo of rat hippocampal neurons by wildtype Alzheimer amyloid precursor protein overexpressed by adenovirusmediated gene transfer. J. Neurosci. 18, 2387-2398.

Nishimura, I., Uetsuki, T., Kuwako, K., Hara, T., Kawakami, T., Aimoto, S., Yoshikawa, K., 2002. Cell death induced by a caspase-cleaved transmembrane fragment of the Alzheimer amyloid precursor protein. Cell Death Differ. 9 199-208.

Noda-Saita, K., Terai, K., Iwai, A., Tsukamoto, M., Shitaka, Y., Kawabata, S., Okada, M., Yamaguchi, T., 2004. Exclusive association and simultaneous appearance of congophilic plaques and AT8-positive dystrophic neurites in Tg2576 mice suggest a mechanism of senile plaque formation and progression of neuritic dystrophy in Alzheimer's disease. Acta Neuropathol. 108, 435-442.

Otth, C., Concha, I.I., Arendt, T., Stieler, J., Schliebs, R., Gonzalez-Billault, C., Maccioni, R.B., 2002. AbetaPP induces cdk5-dependent tau hyperphosphorylation in transgenic mice Tg2576. J. Alzheimers Dis. 4, 417-430.

Qu, D., Li, O. Lim, H.Y., Cheung, N.S., Li, R., Wang, J.H., Oi, R.Z., 2002. The protein SET binds the neuronal Cdk5 activator p35nck5a and modulates Cdk5/p35nck5a activity. J. Biol. Chem. 277, 7324-7332.

Rankin, C.A., Sun, Q., Gamblin, T.C., 2005. Pseudo-phosphorylation of tau at Ser202 and Thr205 affects tau filament formation. Brain Res. Mol. Brain Res. 138, 84-93.

Reeves, R.H., Irving, N.G., Moran, T.H., Wohn, A., Kitt, C., Sisodia, S.S., Schmidt, C. Bronson, R.T., Davisson, M.T., 1995. A mouse model for Down syndrome exhibits learning and behaviour deficits. Nat. Genet. 11, 177-184.

Rueda, N., Florez, J., Martinez-Cue, C., 2011. The Ts65Dn mouse model of Down syndrome shows reduced expression of the $\mathrm{Bcl}-\mathrm{X}(\mathrm{L})$ antiapoptotic protein in the hippocampus not accompanied by changes in molecular or cellular markers of cell death. Int. J. Dev. Neurosci. 29, 711-716.

Ryoo, S.R., Jeong, H.K., Radnaabazar, C., Yoo, J.J., Cho, H.J., Lee, H.W., Kim, I.S. Cheon, Y.H., Ahn, Y.S., Chung, S.H., Song, W.J., 2007. DYRK1A-mediated hyperphosphorylation of Tau. A functional link between Down syndrome and Alzheimer disease. J. Biol. Chem. 282, 34850-34857.

Seo, S.B., McNamara, P., Heo, S., Turner, A., Lane, W.S., Chakravarti, D., 2001. Regulation of histone acetylation and transcription by INHAT, a human cellular complex containing the set oncoprotein. Cell 104, 119-130.

Shukkur, E.A., Shimohata, A., Akagi, T., Yu, W., Yamaguchi, M., Murayama, M. Chui, D., Takeuchi, T., Amano, K., Subramhanya, K.H., Hashikawa, T., Sago, H., Epstein, C.J., Takashima, A., Yamakawa, K., 2006. Mitochondrial dysfunction and tau hyperphosphorylation in Ts1Cje, a mouse model for Down syndrome. Hum. Mol. Genet. 15, 2752-2762.

Strydom, A., Chan, T., King, M., Hassiotis, A., Livingston, G., 2013. Incidence of dementia in older adults with intellectual disabilities. Res. Dev. Disabil. 34 1881-1885.

Sturgeon, X., Gardiner, K.J., 2011. Transcript catalogs of human chromosome 21 and orthologous chimpanzee and mouse regions. Mamm.Genome. 22, 261-271.

Tramutola, A., Lanzillotta, C., Arena, A., Barone, E., Perluigi, M., Di Domenico, F., 2016 Increased mammalian target of rapamycin signaling contributes to the accumulation of protein oxidative damage in a mouse model of Down's syndrome. Neurodegener Dis. 16, 62-68.

von Lindern, M., van Baal, S., Wiegant, J., Raap, A., Hagemeijer, A., Grosveld, G., 1992. Can, a putative oncogene associated with myeloid leukemogenesis, may be activated by fusion of its 3' half to different genes: characterization of the set gene. Mol. Cell Biol. 12, 3346-3355.

Wang, X., Blanchard, J., Kohlbrenner, E., Clement, N., Linden, R.M., Radu, A., Grundke-Iqbal, I., Iqbal, K., 2010. The carboxy-terminal fragment of inhibitor-2 of protein phosphatase-2A induces Alzheimer disease pathology and cognitive impairment. Faseb J. 24, 4420-4432.

Wegiel, J., Dowjat, K., Kaczmarski, W., Kuchna, I., Nowicki, K., Frackowiak, J., Mazur Kolecka, B., Silverman, W.P., Reisberg, B., Deleon, M., Wisniewski, T., Gong, C.X. Liu, F., Adayev, T., Chen-Hwang, M.C., Hwang, Y.W., 2008. The role of overexpressed DYRK1A protein in the early onset of neurofibrillary degeneration in Down syndrome. Acta Neuropathol. 116, 391-407.

Woods, Y.L., Cohen, P., Becker, W., Jakes, R., Goedert, M., Wang, X., Proud, C.G., 2001. The kinase DYRK phosphorylates protein-synthesis initiation factor eIF2Bepsilon at Ser539 and the microtubule-associated protein tau at Thr212: potentia role for DYRK as a glycogen synthase kinase 3-priming kinase. Biochem. J. 355 609-615.

Zhao, M., Su, J., Head, E., Cotman, C.W., 2003. Accumulation of caspase cleaved amyloid precursor protein represents an early neurodegenerative event in aging and in Alzheimer's disease. Neurobiol. Dis. 14, 391-403. 